\title{
Square Grids in the Tomb of Akhethotep Questions and Doubts
}

\author{
KRZYSZTOF RADTKE
}

\begin{abstract}
The proportions of the human figure in Egyptian art were determined on the basis of simple and rarely changing rules. The oldest preserved guidelines used for this purpose come from the times of the Fifth Dynasty, and the square grids from the mid-Twelfth Dynasty. The objective of this article is to interpret the guidelines from the chapel of vizier Akhethotep, dated to the Fifth Dynasty, and answer the following questions: when were they made and what rules were used to determine the proportions of the vizier's body? To do this, the author proposes employment of a measuring method which uses square grids as the main tool and the smallest element of the grid, that is, the square module as the basic measurement unit.
\end{abstract}

Keywords: reliefs, human proportion in art, hypothetical square grid, guidelines, Akhethotep, Old Kingdom Egypt

Krzysztof Radtke, Institute of Mediterranean and Oriental Cultures, Polish Academy of Sciences, Warsaw; kradtke@wp.pl; (D)0000-0002-1143-5769

Analysis of guidelines and square grids preserved mainly on walls of tombs dated to the New Kingdom indicates that the proportions of the human figure in Egyptian art were definitely determined on the basis of simple and rarely changing rules. ${ }^{1}$ However, it is not certain when these rules became binding, although research of a number of scholars, including Gay Robins, suggests that the oldest preserved guidelines on tomb walls used for this purpose come from the times of the Fifth Dynasty, ${ }^{2}$ and the square grids from the mid-Twelfth Dynasty. ${ }^{3}$ The paper discusses one of the early examples of representations

\footnotetext{
1 Panofsky 1955: 55-72; Iversen 1975: 27-37, 55; Schäfer 1974: 163-166, 193; Robins 1983: 17-25; Assmann 1987: 27-28; Brunner-Traut 1990: 12; Pomerantseva 1991: 45-70; Robins 1991: 41-45; 1994: 228-257; 1995: 91-92.

2 Robins 1994: 64-66, Figs 4.1-4.3.

3 Robins 1994: 70-76, Figs 4.8-4.10.
} 
covered by square grids, namely that of the vizier Akhethotep from the times of the Fifth dynasty, the relief situated on the north wall of his funerary chapel. It also aims at analysing the significance of this representation in the discussion on rules adopted in ancient Egypt for determining proportions of the figures.

\section{PRACTICAL RULES OF RENDERING OF REALITY ON FLAT SURFACES}

The characteristic manner of representing the three-dimensional reality on a flat surface in Egyptian art ${ }^{4}$ involved mainly the use of two geometric shapes - the square and the rectangle. Each wall prepared for decoration, which was a surface of one of these shapes, was probably divided into corresponding sectors. The characteristic features of the represented object (the so-called aspects) were determined only in a vertical and horizontal system - without considering perspective, short forms or actual proportions of the representation. ${ }^{5}$ This two-dimensional way of depicting the object is easiest to reconstruct on the basis of the (Cartesian) coordinate system with $\mathrm{x}$ and $\mathrm{y}$ axes, together with measurement points located in it. It seems highly likely that Egyptians used a parallel, although definitely very simplified and less precise, axis system, which facilitated the shaping of the decoration. Due to the fact that the decoration of walls was made in vertical and horizontal bands, the registers of the separate surfaces were situated directly one next to another. As a consequence, they created the impression of a more or less regular network which consisted of crossing or penetrating guidelines, most often perpendicular. As shown by Robins, already at an early stage of the development of Egyptian art, the workshops which prepared decoration on flat surfaces used vertical and horizontal guidelines, as well as grids. ${ }^{6}$ This mainly stemmed from the accepted manner of rendering the reality and was not connected with the chronology of a particular painting or relief. The method and the extent of its use generally evolved in time - starting from thin, finely sketched guidelines ${ }^{7}$ including crossing ones, which mainly served for depiction of characteristic features of the reality, ${ }^{8}$ to regular square grids made with thick cord or ruler and usually red ochre, which were employed for schematic determination of body proportions of the represented person and their surroundings. ${ }^{9}$

\section{THE ROLE OF GUIDELINES AND SQUARE GRIDS IN THE HYPOTHETICAL RECONSTRUCTION OF HUMAN BODY PROPORTIONS}

The question concerning the origin of the proportion system in Egyptian art goes as far back as to the late nineteenth and early twentieth century. Karl Richard Lepsius was one

\footnotetext{
4 Schäfer 1974: 80-159, 163-166; Robins 1994: 1-30.

Brunner-Traut 1974: 428-429; 1990: 12.

6 Robins 1994: 70.

Kuraszkiewicz forthcoming.

Cf. Fisher 1924: Pls 53, 55; Wild 1953: P1. 119.

Cf. Robins 1994: Pls 4.1, 5.3, 5.4, 7.1, 8.1.
} 
of the first to analyse the proportions of the human body in Old Kingdom art by dividing represented human figures with horizontal lines. ${ }^{10}$

According to the Danish Egyptologist Erik Iversen, there was only one, constant, canon of human body proportions throughout the history of ancient Egyptian art. ${ }^{11}$ In order to prove this thesis, Iversen used a hypothetical square grid $^{12}$ to compare a representation of Amenhotep III from tomb KV $22^{13}$ with a selected non-royal representation dated to the Old Kingdom. ${ }^{14} \mathrm{He}$ concluded that ancient artists must have used the constant model of the square grid for determination of human body proportions regardless of the epoch.

The application of the constant model of the square grid in research on human body proportions, described by Iversen, laid the foundations for the method presented by Roland Tefnin. ${ }^{15}$ In his paper of 1983, Tefnin presented a way of employing the hypothetical square grid in the analysis of proportions of the pharaoh's facial features as a measuring tool which was characterised by constant subdivision and constant location of two corners. It must be emphasised that his criteria for the use of the grid, including its subdivision into 256 module elements, are in accordance with those suggested by Iversen. ${ }^{16}$

However, Gay Robins rejected Iversen's assumptions connected with reconstruction of square grids. ${ }^{17}$ She claimed that Iversen broke the rules of scientific objectivity, which was reflected in his arbitrary definition of the measurement points in the analysed representations, and that he attempted to draw conclusions on the basis of just a few hypothetical reconstructions. ${ }^{18}$ It must be stressed that Robins, just like Iversen, also used the hypothetical square grid in her research. ${ }^{19}$ Contrary to Iversen, Robins assumed that it was possible to form reliable theses concerning potential changes in proportions and indirectly also in the style of Egyptian art. She also commented on the method proposed by Tefnin. ${ }^{20}$ She stated that he repeated Iversen's error and adopted an incorrect subdivision of the grid. According to her, the grid was too big and, as opposed to the one consisting of 25 square modules $(5 \times 5)$ that she suggested, did not reflect the practical reasons for its use by ancient artists. ${ }^{21}$ Robins believed that Tefnin's method could have been practically applied since the internal

10 Cf. LD I, 242; Robins 1994: 35-37, Fig. 2.5.

11 Iversen 1975: 55.

12 Iversen used a hypothetical square grid consisting of 256 module elements (16 x 16) for his analysis of human body proportions of the representations for which the original square grid had not been preserved or was invisible.

13 Iversen 1975: Pl. 4.

14 Iversen 1975: P1. 12.

15 Tefnin 1983: 153-177; Radtke forthcoming.

16 Iversen 1976: 135-148.

17 Robins 1994: 44-56.

18 Robins 1994: 47-48.

19 Robins 1994: 60-63.

20 Robins 1984: 31-41.

${ }^{21}$ Robins 1984: 35. According to Robins, available historical sources did not prove Iversen's claim that Egyptian artists used the square grid of the side length of 16 or 24 square modules. 
division of the grid was reduced..$^{22}$ She also stressed that Tefnin adopted many objective research criteria which were essential for this type of analysis. Above all, he was correct in his identification of constant measurement points of the face and applied the rules consistently to all analysed representations.

The objective of the research conducted by Robins was also to reconstruct the ancient Egyptian method of representing the proportions of the human body with parallel and crossing guidelines. Analysis of the preserved representations led Robins to the conclusion that apart from the horizontal lines used from the Fifth Dynasty, ${ }^{23}$ square grids began to appear on walls of tombs only in the times of the mid-Twelfth Dynasty. ${ }^{24}$ At the same time she noticed that the proportions of the human body in representations from the Eleventh and first half of the Twelfth Dynasty corresponded to the ones characteristic of the Old Kingdom - mainly the Fifth and Sixth Dynasties. ${ }^{25}$ Although Robins mentions that grids were sporadically used in the Old Kingdom, there is no evidence for their application for determination of human body proportions. ${ }^{26}$ According to her, the square grids on pharaoh Djoser panels dated to the Third Dynasty are not sufficient evidence (Figs 1-2). ${ }^{27}$ The grids are well-preserved and cover the ruler's representations. On the basis of analysis of their structure, Robins concluded that they exemplify work done by copyists in the Saite period. ${ }^{28}$ It should be added that in most publications the ancient Egyptian phenomenon of copying representations with application of square grids is mainly associated with technical aspects of the decoration process and general rules of depicting the reality on flat surfaces. ${ }^{29}$ Although Robins characterises the grids of Djoser panels without analysing this case in a broader context (e.g. by referring to parallels or examples of other grid subdivisions), her argumentation is convincing and her conclusions are justified. However, in the case of the square grid preserved in the chapel of vizier Akhethotep, dated to the Fifth Dynasty, applying of the same date to the grid as the one suggested for the Djoser panels, that is, the Saite period, raises important doubts. Therefore, two fundamental questions should be asked:

1. When were the grids on the walls of the tomb of Akhethotep made?

2. What rules were used to determine the proportions of Akhethotep's body?

22 Robins 1984: 37.

${ }^{23}$ Robins 1994: 64, Figs 4.1-4.5.

${ }^{24}$ Robins 1994: 70-73.

${ }_{25}$ The horizontal lines from the Eleventh to the mid-Twelfth Dynasty were distributed identically to the lines from the Old Kingdom.

${ }^{26}$ Cf. Robins 1994: 70. Nevertheless, Robins believes that square grids were also used for establishing human body proportions in the Old Kingdom, although there is no evidence for that. This likelihood of the use of grids resulted mainly from the accepted way of representation of reality on flat surfaces, observed by ancient Egyptians.

${ }^{27}$ Djoser panels are situated in subterranean chambers under the Step Pyramid at Saqqara (cf. Friedman 1995: 1-42).

${ }^{28}$ Robins 1994: 169-170. Other authors also use such arguments; cf. Morkot 2003: 85-88.

${ }^{29}$ Robins 1994 23-29; Kanawati 2011: 483-496; Bács 2020: 149. 


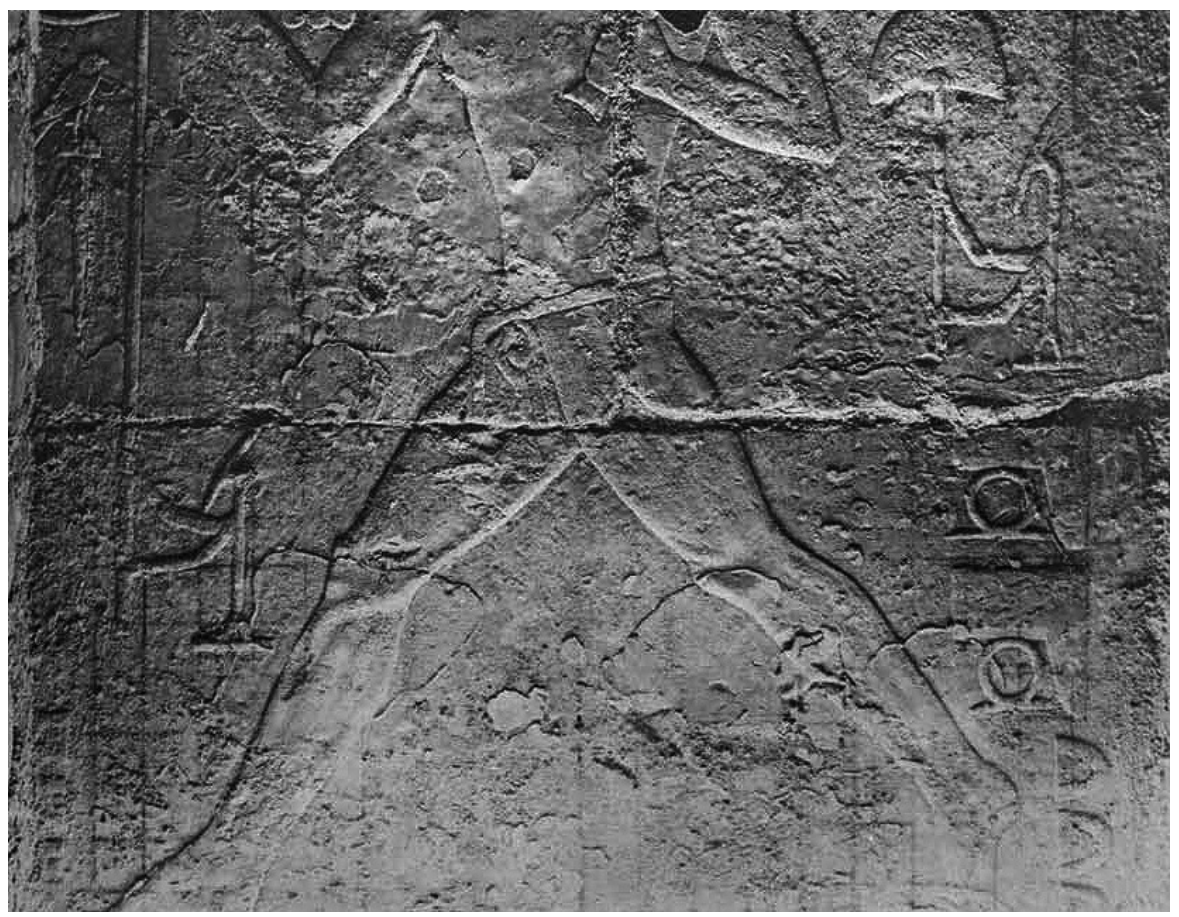

1. Square grid on Djoser's panel in the subterranean chambers of the Step Pyramid at Saqqara (Firth, Quibell 1935: Pl. 15).

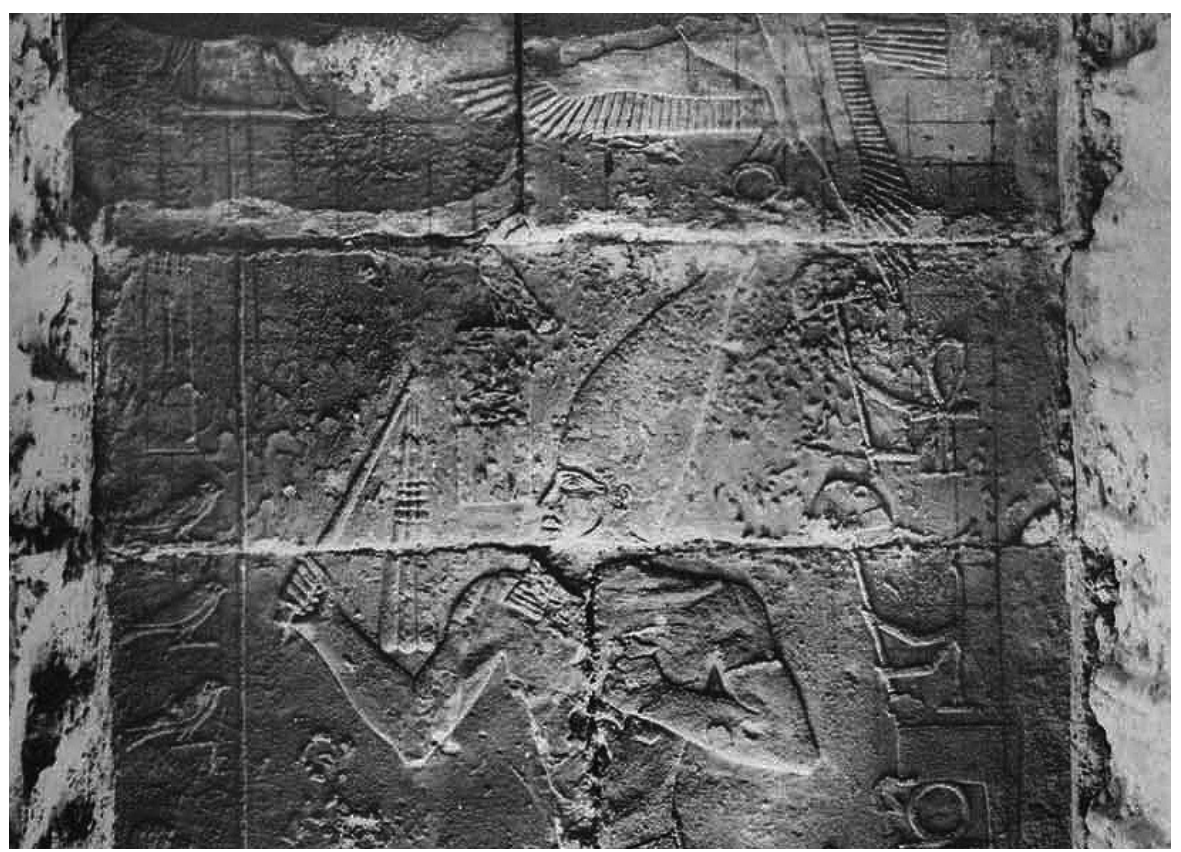

2. Square grid on Djoser's panel from the Step Pyramid at Saqqara (Firth, Quibell 1935: Pl. 16). 


\section{CHARACTERISTICS OF THE GRIDS IN THE CHAPEL OF AKHETHOTEP}

The location of the tomb of Ahkethotep ${ }^{30}$ high quality of the decorations, but most of all the numerous titles of the vizier, found on the walls of the chapel, ${ }^{31}$ indicate that he was an important person at the court of pharaoh Djedkare Isesi. The reliefs from this tomb are at the moment a part of the collection of the Louvre Museum (E 10958A). ${ }^{32}$ Although the decoration on the walls of the tomb has been partially renovated, the course of the regularly spaced preserved lines, also above the seated vizier's head, indicates that they covered the whole scene (Fig. 3). The square grid, partially reconstructed recently, is best visible on the right portion of the wall, where depictions of the offerings and offering bearers are situated. ${ }^{33}$ Fragments of grids have also been preserved in other parts of the chapel, ${ }^{34}$ but they do not cover the figure of the vizier. Nevertheless, in all cases, regardless of the part of the tomb, the lines of the same grid can be seen both on the convex surface of the relief and on the sunken background situated below. For this reason, it should be assumed that the crossing guidelines at the chapel of Akhethotep were made after the decoration had been finished.

Horizontal guidelines have been preserved on walls of many Old Kingdom tombs. ${ }^{35}$ Nevertheless, already in that period, crossing lines, more or less regular, usually subtly marked, appeared on walls of religious structures. These lines cover not only the representation of human figures but also a fragment of the wall prepared for decoration. ${ }^{36}$ They did not form regular square grids, but their application was an integral part of the adopted method of representation of the three-dimensional reality on flat surfaces. For this reason, it does not seem possible that such accurate and clearly marked grid lines from the chapel of Akhethotep could have been drawn in the Old Kingdom. Their authors were proficient at the technique of marking crossing lines, which suggests that the grid in question was a significantly later solution. Considering the reconstructed form of the grid, based on the best-preserved square module from the chapel of Akhethotep, it can be concluded that it was a regular and precisely laid out structure (Fig. 4). The height of the seated vizier can be estimated at 14 square modules (from the soles up to the hairline). ${ }^{37}$ The present state of knowledge indicates that such a height of a seated person's body is characteristic of

30 The tomb is located at the Saqqara necropolis between the mortuary complexes of the pharaohs Djoser (Third Dynasty) and Unas (Fifth Dynasty).

31 The most important titles of Akhethotep include: the priest of Horus, priest of Heka, priest of Khnum, sole friend and leader of the two thrones (Cf. Ziegler et al. 2007: 24-25).

32 Cf. Chapel tomb Akhethotep.

33 Ziegler 1993: 48-49.

34 Cf. Saqqara.

35 Cf. Davies 1902: P1. 6; Fisher 1924: Pls 53, 55; Saleh 1977: P1. 17; Robins 1994: 64-69.

36 Smith 1949: Fig. 95.5; Kuraszkiewicz forthcoming. In the Old Kingdom, crossing lines which formed the square grid were sporadically used to highlight the shape of rippling water (cf. Wild 1953: Pl. 119) or in the areas where offering lists were placed (cf. Iversen 1975: Pl. I.I).

37 Although the reconstructed horizontal lines do not cross the hairline and the soles of the feet (cf. Robins 1994: 76, Figs 4.11-4.12), and additionally the error of the reconstructed grid could reach (+/-) $0.1-0.2$ square module, it seems most likely that the artists used a grid which was 14 squares high. 


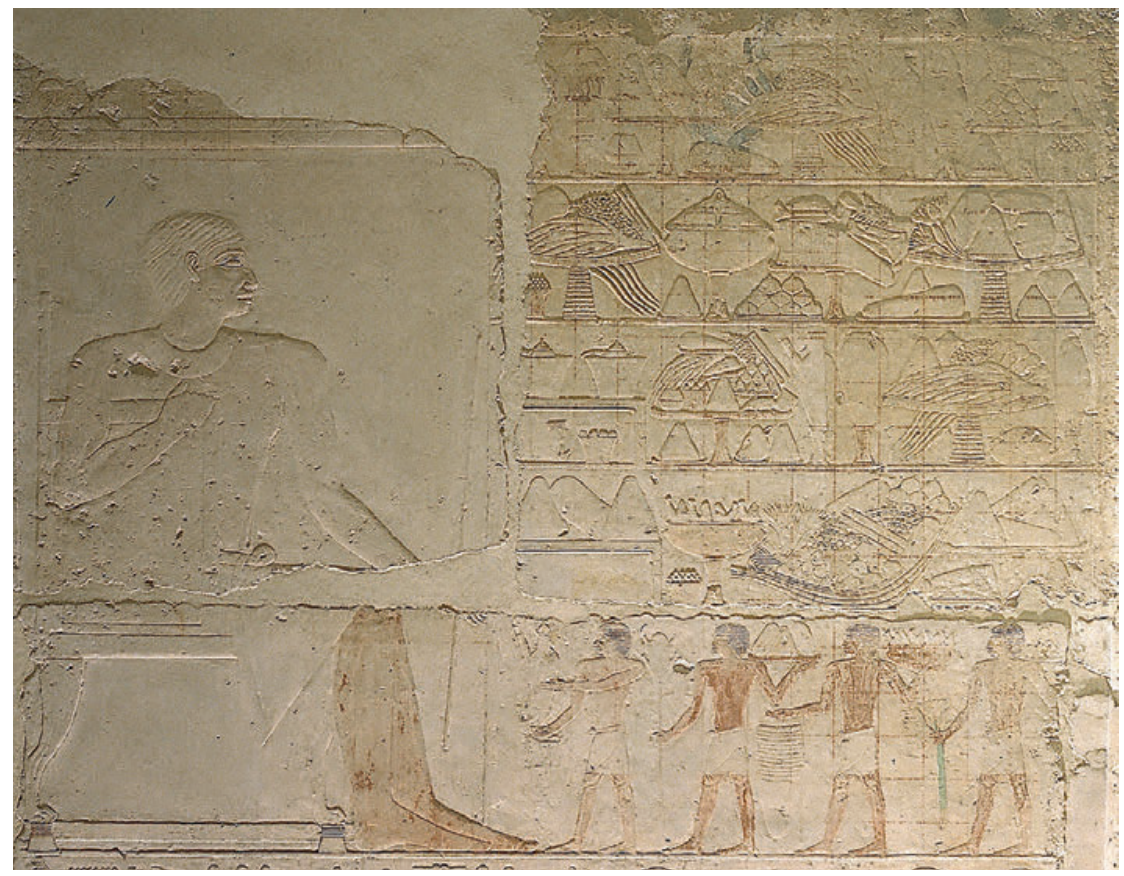

3. Preserved square grids on the north wall (upper register) of the funerary chapel of vizier Akhethotep (Fifth Dynasty, Saqqara); Louvre, E 10958A (Chapelle de la tombe d'Akhethetep 2).

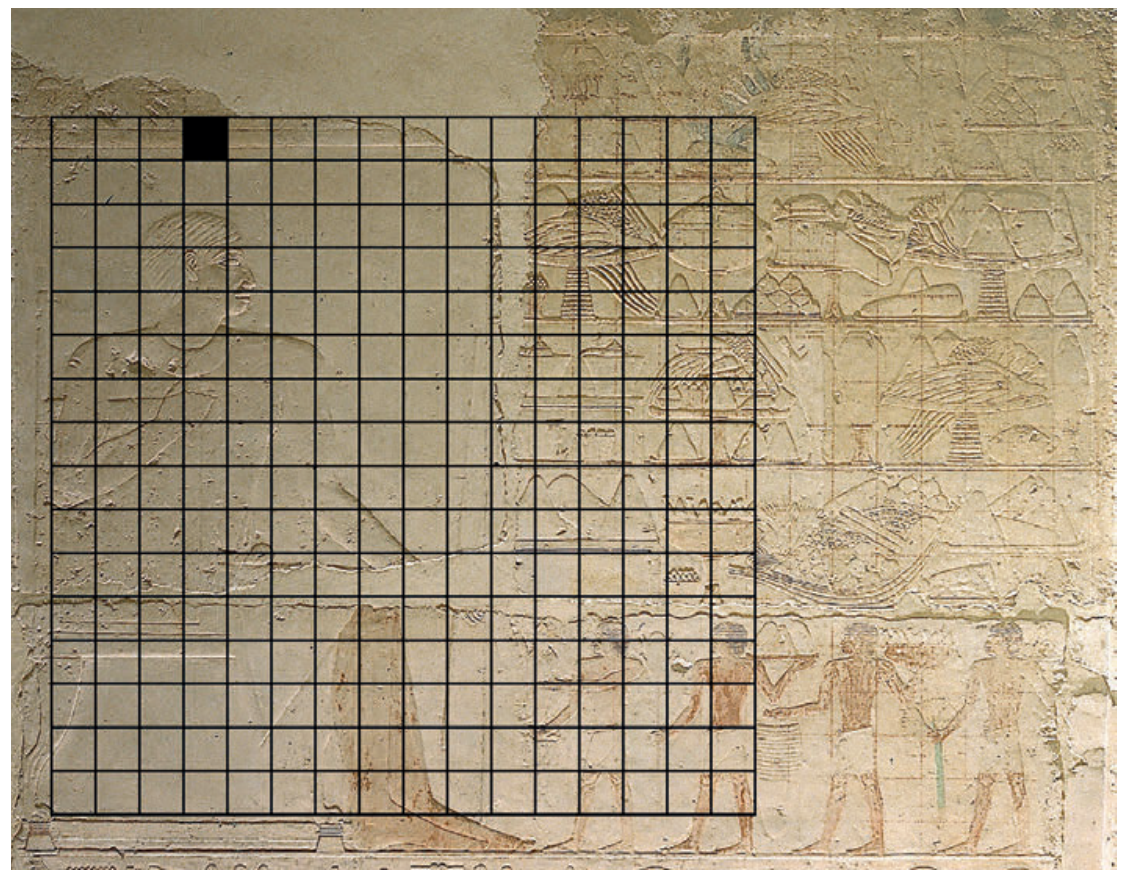

4. Reconstructed grid from the funerary chapel of Akhethotep (Chapelle de la tombe d'Akhethetep 2). 
the so-called early system. ${ }^{38}$ The beginnings of the above-mentioned system would reach back to the Twelfth Dynasty, and not the Old Kingdom. Such a type of grids disappeared at the end of the New Kingdom. In the so-called later system ${ }^{39}$ both the body proportions and grid division differ from the previous one. ${ }^{40}$ For this reason, it seems unlikely that the grids from the chapel of Akhethotep, characteristic of the early system, could be the work of copyists from the Saite period, ${ }^{41}$ like those attested on the Djoser panels. If the grids on Akhethotep's representations were examples of decorators' practical exercises, the activity of these artists would rather have fallen to the time of the functioning of the early system. Apart from that, the clearly marked long lines made with red ochre, which are systematically distributed on the walls of Akhethotep's tomb, are more likely to indicate potential copyists active in the New Kingdom rather than in a later period. Even the partially preserved grid lines over the representation of the vizier imply that they were used not merely for a mechanic copying of an image, but also for precise rendering of the proportions of different parts of the body.

\section{APPLICATION OF HYPOTHETICAL SQUARE GRIDS IN THE ANALYSIS OF AKHETHOTEP'S REPRESENTATIONS}

The measurement method which will be used to find answers to the second research question largely draws upon the assumptions listed by Tefnin ${ }^{42}$ and by Iversen - mainly with regards to the rules and manner of application of the hypothetical square grid. It also complies with Robins's suggestions that such an analysis should meet objectivity criteria, particularly by following unalterable rules, including the location of constant measurement points. The method focusses on technical and practical aspects of taking measurements, ${ }^{43}$ and is thus closer to scientific metrology ${ }^{44}$ or statistics than to historical metrology. ${ }^{45}$

38 Cf. Robins 1994: 164-169, 259.

39 Robins 1994: 160-164. As opposed to the so-called early system, in which the height of a seated human figure was constant and reached 14 squares, in the late system it was usually represented as 16 or 17 squares tall.

${ }^{40}$ Robins observed that the first square grids that could be representative for the later grid system appeared already during the Twenty-Fifth Dynasty (e.g. chapel of Amenirdis I at Medinet Habu), and not, as it was previously believed, in the times of the Twenty-Sixth Dynasty (cf. Mackay 1917: 83; Iversen 1975: 75). According to her, the system was most likely in use until the end of the Late period.

${ }^{41}$ A less likely hypothesis could also be considered, namely, that the grids in the chapel of Akhethotep are examples of practical exercises of Saite copyists or possibly relics of work of Late period copyists, who used grids typical of the earlier system to reproduce older representations; for copying as a practical exercise and a method of work of copyists, see: Robins 2001: 60-62; Lashien 2010: 81-84; Kanawati 2011: 483-496; Bács 2020: 148-151.

42 Tefnin 1983: 153-177; Radtke 2011: 160-183.

43 It should also be noted that from the methodological point of view, the measurement techniques, together with this analysis, form an integral part of the formal analysis of an art piece (cf. Skubiszewski 1973: 251). Considering that the formal analysis is, apart from the iconographic one, the most important component of a detailed description of an art piece (cf. Skubiszewski 1973: 227-265), application of such a method for analysis of Egyptian art pieces seems totally justified.

44 Sobol 1995: 472.

45 Szymański 2001: 154. 
It is important to stress that the objective of the survey described below was not a theoretical reconstruction of the original location of the potential guidelines. ${ }^{46}$ The hypothetical square grids were used in the analysis as a tool for estimation of the proportions and locations of particular parts of the body. The hypothetical square grid will also be employed to identify the scale of similarities between Akhethotep's representation in question with another of his depiction. ${ }^{47}$

\section{RULES OF APPLICATION OF TWO MODELS OF HYPOTHETICAL SQUARE GRIDS}

\section{IN THE MEASUREMENT METHOD}

To strengthen the reliability of the study, two different models of hypothetical grids consisting of different numbers of squares were used. In both cases the following assumptions were adopted:

- the length of the side of the hypothetical square grid, and as a result its size, is not constant and depends on the distance between its two constant points (corners of the grid); - the constant points of the grid are: no. 1. the lower border of the wig (hairline) or another headdress over the forehead and the point where the vertical line running across the lower border of the headdress, below referred to as A, crosses the horizontal line, below referred to as B; no. 2. the point of the junction of the neck with shoulders, that is, the point where lines A and B1 cross (Fig. 5a); ${ }^{48}$

- the measurements are taken starting from the top part towards the bottom part of the representation, that is from the lower border of the wig/headdress over the forehead towards the soles of the feet;

- the main measurement unit is the smallest element of the grid, that is, the square module; - the distance from the measurement point to the lines of the grid is expressed in the number of square modules;

- due to the state of preservation of the reliefs (damage), accuracy in shaping the details, varying quality of the photos, the measurement error ${ }^{49}$ was estimated at (+/-) $0.1-0.2$ of the size of the square module..$^{50}$

${ }^{46}$ Further discussion is thus unconnected with research on methods and techniques of work used by ancient artists, also in the context of the use of guidelines and square grids as tools for establishing proportions and dimensions of human figures represented on flat surfaces.

${ }^{47}$ Cf. Fig. 7e-f.

${ }^{48}$ Lepsius, among others, regarded the lower border of the wig/headdress over the forehead and the junction of the neck with shoulders as critical points used in the art of the Old Kingdom to determine human body proportions. Constant (horizontal) guidelines established by Lepsius crossed these points (cf. Schäfer 1919: P1. 107; Robins 1994: Fig. 2.5).

49 The measurement error should be understood as the difference between the measurement result and the actual value of the measured magnitude.

${ }^{50}$ Depending on the size and quality of the photograph of the analysed image, lines of the overlaid square grids could represent varying thickness. However, it should be added that the thickness of grid lines within a given analysed image is always the same, grid lines of two different thicknesses were used in this study. The possible resulting defects in precision are within the range of the assumed measurement error, that is (+/-) $0.1-0.2$ of the square module. 

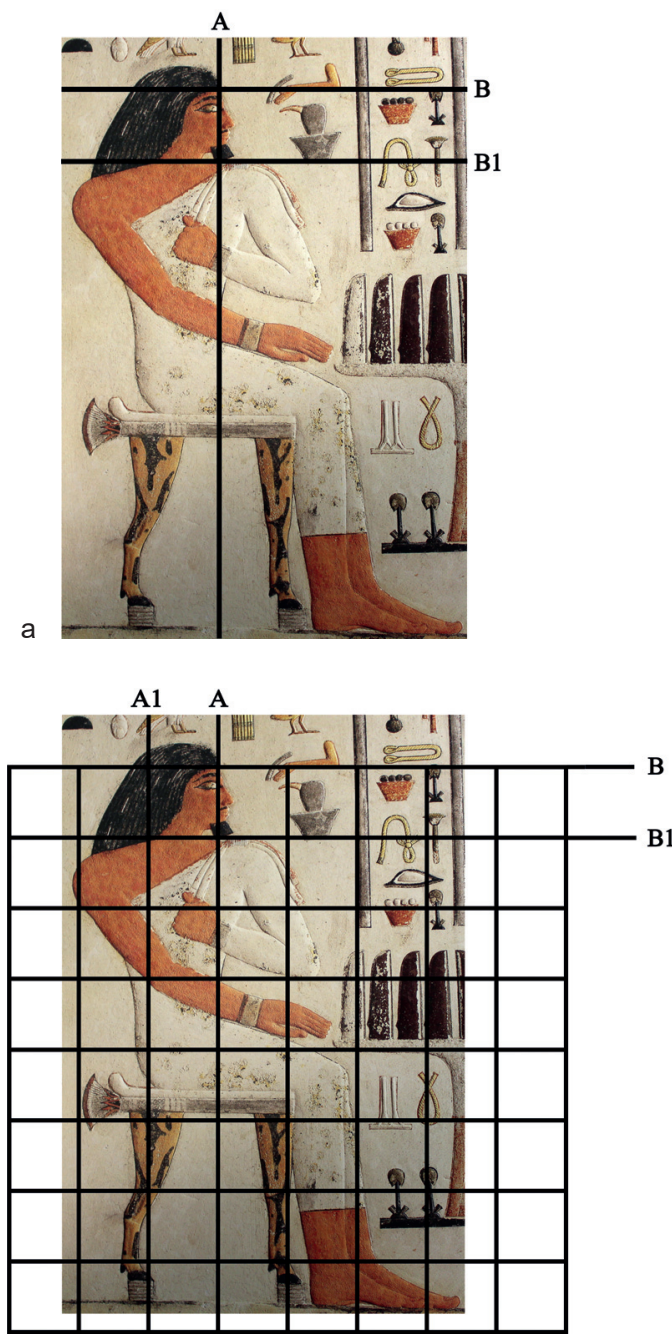

C

5. Representation of Wepemnefer (mastaba G 1201, Giza, Fourth Dynasty) as an example showing the rules of application of the hypothetical square grid: a. location of the constant corner points of the grid; b. manner of determination of the size of the square module in grid no. 1; c. grid no. 1 model; d. grid no. 2 model (based on: O’Neil (Ed.) 1999: cat. no. 52).

In model one (grid no. 1), the length of the side of the smallest grid element (square module) is defined by the distance between the lower border of the wig/headdress and the junction of the neck with shoulders. At the same time, when the vertical line A and horizontal lines B and B1 cross them, these two points (cf. constant points nos 1 and 2) form two corners of the square module. The distance between these points is also the length of the side of the square module (Fig. 5b). The remaining sides of the square module were marked by copying this line segment. Then the square module is copied from the hairline 
towards the soles of the feet to cover the whole figure. Due to the fact that the number of square modules in the grid depends on the size of the smallest element and the distance between the constant corner points, the square grid drawn in this way usually exceeds the area limited by the soles of the feet (Fig. 5c).

In the other model (grid no. 2), the square grid for a seated human figure is defined on the basis of the constant point no. 1 and the soles of the feet (Fig. 5d), and divided, like in the early grid system, into 196 square modules $(14 \times 14) .^{51}$

\section{ANALYSIS OF MEASUREMENT VALUES}

More detailed conclusions can be draw on the basis of the comparison of measurement values for the two reliefs of Akhethotep and of Thutmose III found on a wooden drawing board stored in the British Museum EA 5601 (Fig. 6)..$^{52}$ The grid on the wooden board was probably drawn at the same time as the portrait of Thutmose III and, therefore, both seem to form unity. The wooden board possibly shows the set of basic guidelines for artists who depicted the seated king. It must be added that the subdivision of the square grid on this object is one of the best-preserved examples for the practical application of the early grid system to establish body proportions ${ }^{53}$ of a seated person in Egyptian art.

The comparison of proportions of the representations of seated Thutmose III and Akhethotep by means of the two hypothetical grid models shows that these images are very similar to each other. For instance, the lines running across the same places include the ones crossing the junction of the neck with shoulders (Fig. $7 \mathbf{b}$, d ; grid no. 2, horizontal line 2), the bend of the elbow of one arm (horizontal line 6), ankles (horizontal line 13) and probably the bend of the knee (horizontal line 8). However, the widths of the analysed representations (horizontal measurements) are different.

These differences are best visible when the distances between the back of the throne and the bend of the knees as well as between the farther leg of the throne and the most protruding toe are compared.

Application of another hypothetical grid model (grid no. 1) also indicates significant similarities between the examined images (Fig. 7a, c). These are corresponding heights of 7 square modules and same points of crossing of all vertical lines. What should also be added is that in the case of another depiction of seated Akhethotep from his funerary chapel (Fig. 7e-f), the body proportions and the crossing points of the horizontal lines of both grid models (grids nos 1 and 2) are parallel to the ones defined in the previously analysed representations.

Detailed results of measurements of the representations of Akhethotep and Thutmose III are listed in Tab. 1.

${ }^{51}$ In the early grid system (cf. Robins 1994: 70-86) the height of a seated human figure, measured from the lower border of the wig/headdress over the forehead to the soles of the feet, was 14 square modules.

${ }_{52}$ Russmann (Ed.) 2001: 153-154; Robins 1994: 87-94, P1. 5.1.

${ }_{53}$ The proportions of the analysed representation of seated Thutmose III are the same as those observed in Middle Kingdom art (cf. Robins 1994: 87). 


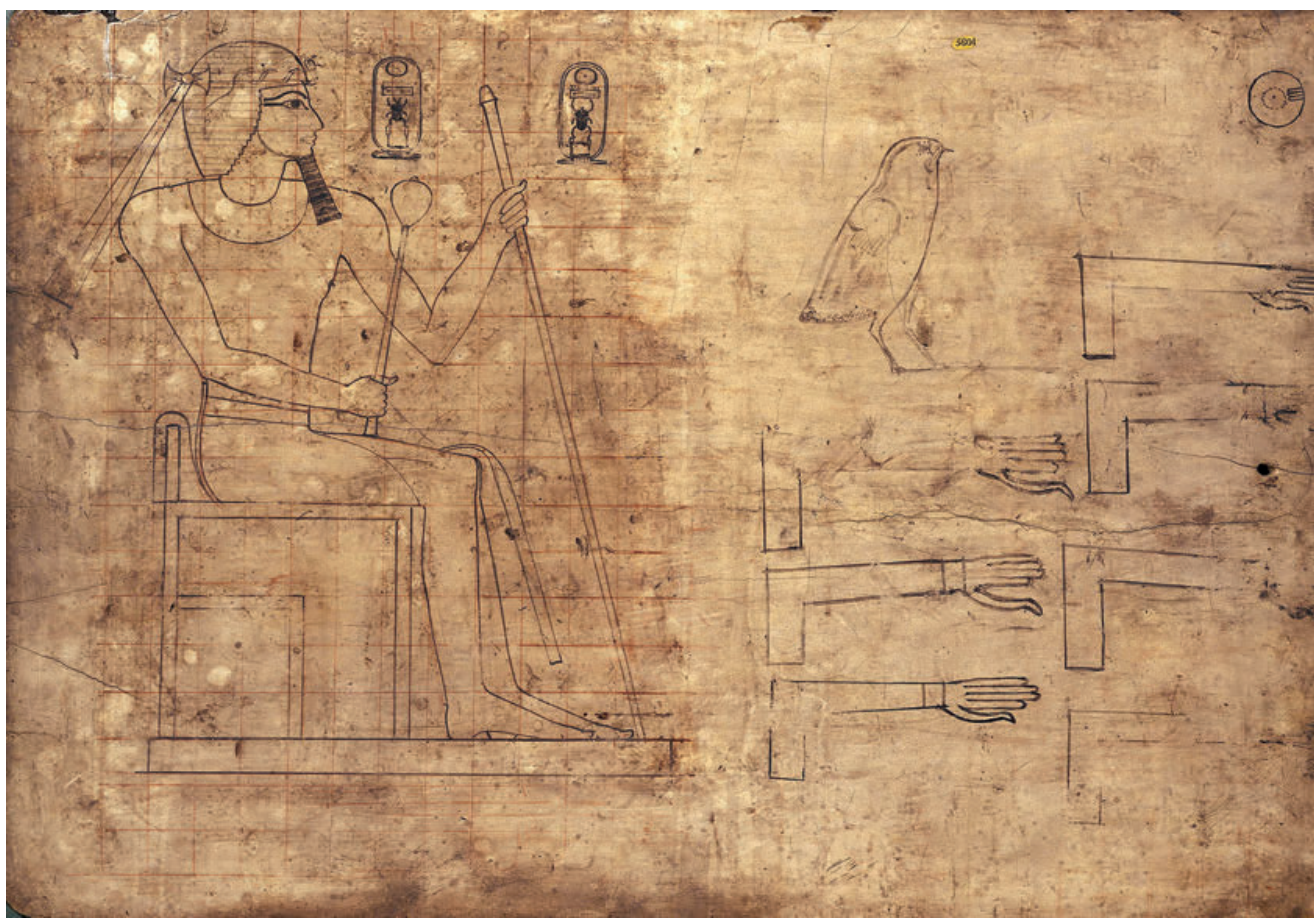

6. Wooden drawing board dated to the reign of Thutmose III (Eighteenth Dynasty); British Museum, EA 5601 (Russmann (Ed.) 2001: cat. no. 66).

Tab 1. Detailed measurements value (square modules) of the particular parts of the body (according to two different hypothetical grids) of the representations of Thutmose III (wooden drawing board from EA 5601) and two representations of Akhethotep (north wall, upper register of the funerary chapel and from the vizier's chapel E 10958A, respectively).

\begin{tabular}{|l|c|c|c|c|c|c|}
\hline \multirow{2}{*}{ Part of the body } & \multicolumn{2}{|c|}{$\begin{array}{c}\text { Thutmose III } \\
\text { (Fig. 7a-b) }\end{array}$} & \multicolumn{2}{c|}{$\begin{array}{c}\text { Akhethotep } \\
\text { (Fig. 7c-d) }\end{array}$} & \multicolumn{2}{c|}{$\begin{array}{c}\text { Akhethotep } \\
\text { (Fig. 7e-f) }\end{array}$} \\
\cline { 2 - 7 } & grid 1 & grid 2 & grid 1 & grid 2 & grid 1 & grid 2 \\
\hline Junction of the neck with shoulders & 1 & 2 & 1 & 2 & 1 & 2 \\
\hline Chest at the level of nipples & 2.1 & 4.2 & 2.1 & 4.2 & 2.1 & 4.2 \\
\hline $\begin{array}{l}\text { Bend of the elbow (of the arm bent } \\
\text { to a greater degree) }\end{array}$ & 3 & 6 & 3 & 6 & 3 & 6 \\
\hline $\begin{array}{l}\text { Bend of the other elbow (of the arm } \\
\text { positioned lower) }\end{array}$ & 3.2 & 6.3 & 3 & 6 & 3.2 & 6.4 \\
\hline Lumbar part of the spine & 3.2 & 6.3 & $3.2(?)$ & $6.3(?)$ & $3.2(?)$ & $6.3(?)$ \\
\hline Bend of the knee & 4 & 8 & $4(?)$ & $8(?)$ & 4 & 8 \\
\hline Ankle & 6.5 & 13 & 6.5 & 13 & 6.5 & 13 \\
\hline
\end{tabular}




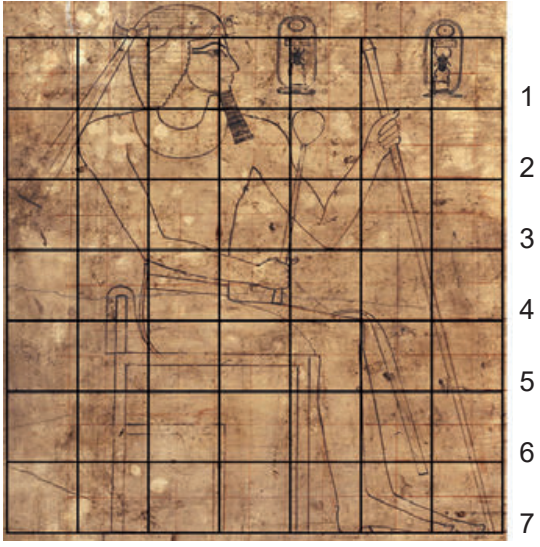

a

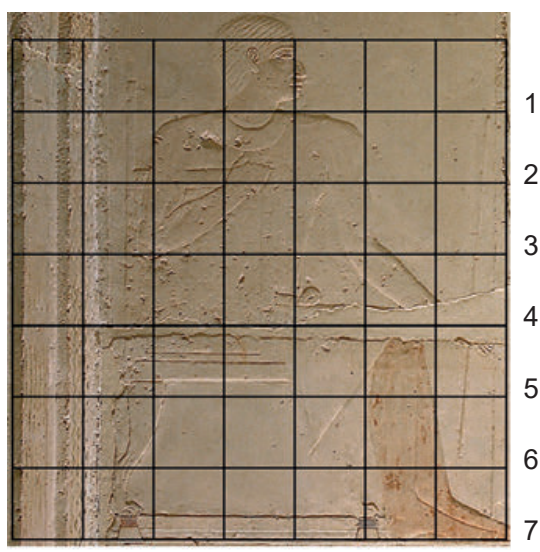

C

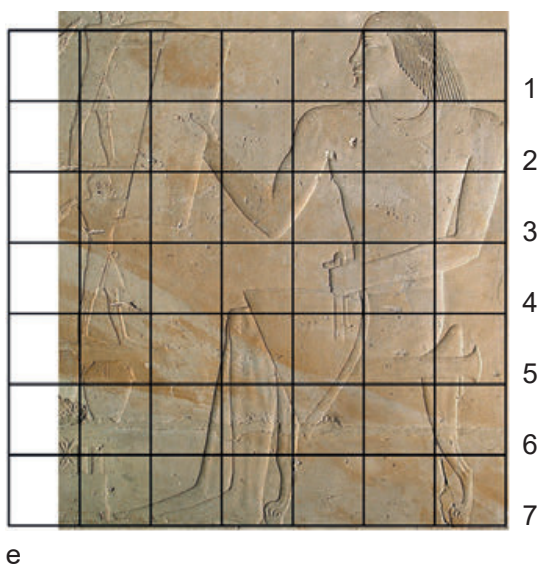

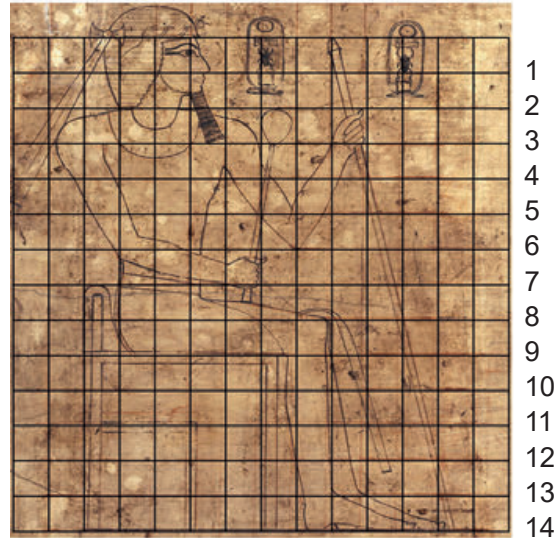
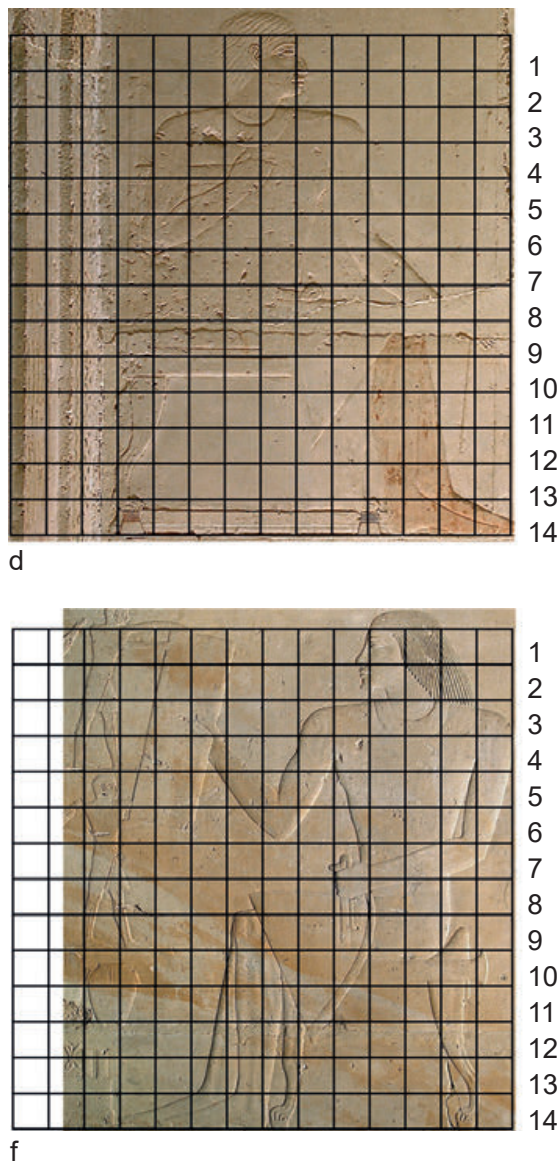

7. Comparison of body proportions in the representations of Thutmose III and Akhethotep with grids nos 1 and 2 (based on: a-b. Russmann (Ed.) 2001: cat. no. 66; c-d. Chapelle de la tombe d'Akhethetep 2; e-f. Chapelle de la tombe d'Akhethetep). 


\section{CONCLUSIONS AND THE AREA OF FURTHER RESEARCH}

There is no doubt that only a comparative analysis of a larger assemblage of images which are representative for a particular period can lead to drawing well-founded and detailed conclusions. However, the same or very similar results of measurements taken of the three images analysed above are probably not accidental.

Since the proportions of both representations of Akhethotep are very similar to those of representation of Thutmose III, determined with square grid consisting of 196 modules (14 x 14), it is reasonable to deduce that already the authors of the decoration in the chapel of the vizier used a similar method for establishing body proportions as the artists in the royal workshops of the Eighteenth Dynasty. Thus it seems that they might have used not only the horizontal guidelines spaced at equal intervals, but also perpendicular lines, which divided the decorated surface into sectors that simplified the work. However, if the decorators of the vizier's chapel did not use such a technique, it remains unknown what auxiliary tools they used to determine the proportions of his body with such accuracy and in accordance with the early grid system.

The arguments listed above seem to justify another hypothesis. Due to the fact that the grid was overlaid on a finished decoration, the grid most probably must have been drawn by copyists who worked in the tomb of Akhethotep in the New Kingdom. Such a possibility is mainly corroborated by the grid subdivision, ${ }^{54}$ as well as the high quality and accuracy of the structure of the crossing lines. It seems that the suggestion mentioned above, ${ }^{55}$ proposing Late period copyists as the authors of the grids in the chapel of Akhethotep, is less likely.

Further comparative studies should also lead to the answer to other, more detailed, questions. One of the best documented and well-preserved horizontal lines which can be found in many representations crosses the human silhouette at the juncture of neck and shoulders. ${ }^{56}$ Hypothetical grid no. 2 was used to divide each of the analysed representations into two equal parts, starting from that line and reaching the soles of the feet. The midline of this division crosses knees (line no. 8), which play a key role in the preservation of the proportions between the upper and lower part of the body. A comparison of a big group of reliefs, especially with application of hypothetical grid no. 2, might settle whether the division which omitted the head was indeed used by Egyptians and whether such separation of this part of the body meant that they employed different, possibly individual rules to shape it. The differences in the measurement values of the bend of the elbow of the arm positioned lower and the measurement uncertainty in the case of the lumbar part of the spine also raise doubts of interpretation. It appears that the location of these parts of the body could have been of lesser importance to the decorators when they established fundamental body

${ }^{54}$ Examples of parallel and original grids can be found on the walls of Theban non-royal tombs, e.g. TT 22 (Wah and Meryamun), TT 89 (Amenmose); cf. Mackay 1917: 35-37; Robins 1994: 87, 94, P1. 5.2; Brock, Shaw 1997: 167-177.

${ }^{55} \mathrm{Cf}$. above, footnote 41.

56 See above, footnote 50 . 
proportions of the represented persons. This hypothesis, like all the previously mentioned ones, also requires future comparative analyses to be either confirmed or rejected.

\section{References}

Assmann, J. 1987: Hierotaxis. Textkonstitution und Bildkomposition in der altägyptischen Kunst und Literatur, [in:] Osing, J., Dreyer, G. (Eds), Form und Maß. Beiträge zur Literatur, Sprache und Kunst des alten Ägypten, ÄAT 12, Wiesbaden, 18-42

Bács, T. 2020: When Ancient Egyptians Copied Egyptian work, [in:] Davies, V., Laboury, D.

(Eds), The Oxford Handbook of Egyptian Epigraphy and Palaeography, New York, $147-162$

Brock, L.P., Shaw, R.L. 1997: The Royal Ontario Museum Epigraphic Project - Theban Tomb 89 Preliminary Report, JARCE 34, 167-177

Brunner-Traut, E. 1974: Epilogue: Aspective, [in:] Schäfer, H., Principals of Egyptian Art,

Ed. Brunner-Traut, E., Baines, J., Oxford, 423-446

Brunner-Traut, E. 1990: Frühformen des Erkennens am Beispiel Altägyptens, Darmstadt Chapelle de la tombe d'Akhethetep: www.louvre.fr/en/mediaimages/chapelle-de-la-tombed-akhethetep (accessed July 17, 2018)

Chapelle de la tombe d'Akhethetep 2: www.louvre.fr/en/mediaimages/chapelle-de-la-tombed-akhethetep-2 (accessed July 17, 2018)

Chapel tomb Akhethotep: https://www.louvre.fr/en/oeuvre-notices/chapel-tomb-akhethotep (accessed July 17, 2018)

Davies, N. de G. 1902: The Rock Tombs of Deir el Gebrâwi II, ASEg XII, London

Firth, C.M., Quibell, J.E. 1935: Excavations at Saqqara: The Step Pyramid, vol. 2: Plates, Cairo

Fisher, C.S. 1924: The Minor Cemetery at Giza, Philadelphia

Friedman, F.D. 1995: The Underground Relief Panels of King Djoser at the Step Pyramid Complex, JARCE 32, 1-42

Iversen, E. 1975: Canon and Proportion in Egyptian Art, Warminster

Iversen, E. 1976: The Proportions of the Face in Egyptian Art, SAK 4, 135-148

Kanawati, N. 2011: Art and Gridlines: The copying of Old Kingdom scenes in later periods, [in:] Bárta, M., Coppens, F., Krejči, J. (Eds), Abusir and Saqqara in the Year 2010, vol. 2, Prague, 483-496

Kuraszkiewicz, K.O. forthcoming: An unorthodox $6^{\text {th }}$ Dynasty tomb at Saqqara - funerary chapel of Ikhy/Mery, Collection Orient \& Méditerranée, Paris

Lashien, M. 2010: Artists' Training in the Old and Middle Kingdoms, GöttMisz 224, 81-84

Mackay, E. 1917: Proportion Squares on Tomb Walls in the Theban Necropolis, JEA 4/2-3, 74-85

Morkot, R. 2003: Archaism and innovation in art from the New Kingdom to the Twentysixth Dynasty, [in:] Tait, J. (Ed.), 'Never had the like occurred': Egypt's view of its past, London, 79-99

O’Neil, J.P. (Ed.) 1999: Egyptian Art in the Age of Pyramids, New York 
Panofsky, E 1955: Meaning in the visual arts: papers in and on Art History, New York

Pomerantseva, N. 1991: The geometrical basis of the proportional canon in ancient Egyptian art, DiscEg 20, 45-70

Radtke, K. 2011: Iconography of the Pharaoh's Face in the Eighteenth Dynasty Relief, EtudTrav XXIV, 159-183

Radtke, K. forthcoming: The iconography of the pharaoh's face in the eighteenth dynasty relief - metric analysis, Travaux de l'Institut des Cultures Méditerranéennes et Orientales de l'Académie Polonaise des Sciences VIII, Warsaw

Robins, G. 1983: Natural and Canonical Proportions in Ancient Egyptians, GöttMisz 61, $17-25$

Robins, G. 1984: Analysis of Facial Proportions in Egyptian Art, GöttMisz 79, 31-41

Robins, G. 1991: Composition and the Artist's Squared Grid, JARCE 28, 41-54

Robins, G. 1994: Proportion and Style in Ancient Egyptian Art, Austin

Robins, G. 1995: Canonical proportions and metrology, DiscEg 32, 91-92

Robins, G. 2001: The use of the squared grid as a technical aid for artists in Eighteenth Dynasty Painted Theban Tombs, [in:] Davies, W.V. (Ed.), Colour and Painting in Ancient Egypt, London, 60-62

Russmann, E.R. (Ed.) 2001: Eternal Egypt: Masterworks of Ancient Art from The British Museum, London

Saleh, M. 1977: Three Old Kingdom Tombs at Thebes, ArchVer 14, Mainz a/Rhein

Saqqara: http://www2.culture.gouv.fr/culture/arcnat/saqqara/fr/chapelle/chapelle_dis/ chapelle_dis2c.htm (accessed July 17, 2018)

Schäfer, H. 1919: Von ägyptischer Kunst, besonders der Zeichenkunst. Eine Einführung in die Betrachtung ägyptischer Kunstwerke, Leipzig

Schäfer, H. 1974: Principles of Egyptian Art, Ed. Brunner-Traut, E., Baines, J., Oxford

Skubiszewski, P. 1973: Pojęcia, kierunki i metody historii sztuki, Elementy metodologii, [in:] Skubiszewski, P. (Ed.), Wstęp do historii sztuki, vol. 1, Przedmiot - Metodologia - Zawód, Warszawa, 227-265

Smith, W.S. 1949: A History of Egyptian Sculpture and Painting in the Old Kingdom, London

Szymański, J. 2001: Nauki pomocnicze historii, Warszawa

Tefnin, R. 1983: Essai d'analyse formelle du visage royal égyptien : un relief de Touthmosis III aux Musées royaux d'Art et d'Histoire de Bruxelles, [in:] Meulenaere, H. de, Limme, L. (Eds), Artibus Aegypti: Studia in honorem Bernardi V. Bothmer a Collegis Amicis Discipulis Conscripta, Bruxelles, 153-177

Wild, H. 1953: Le Tombeau de Ti, Fasc. II : La chapelle (première partie), MIFAO 65/2, Le Caire

Ziegler, C. 1993: Le Mastaba d'Akhethétep. Une chapelle funéraire de l'Ancien Empire, Paris

Ziegler, C., Adam, J.-P., Andreu-Lanoë, G., Bridonneau, C., Étienne, M., Lecuyot, G., Rozières, M.-F. de 2007: Le Mastaba d'Akhethetep, Fouilles du Louvre à Saqqara 1, Louvain 


\section{ÉTUDES et TRAVAUX XXXIII / 2020}
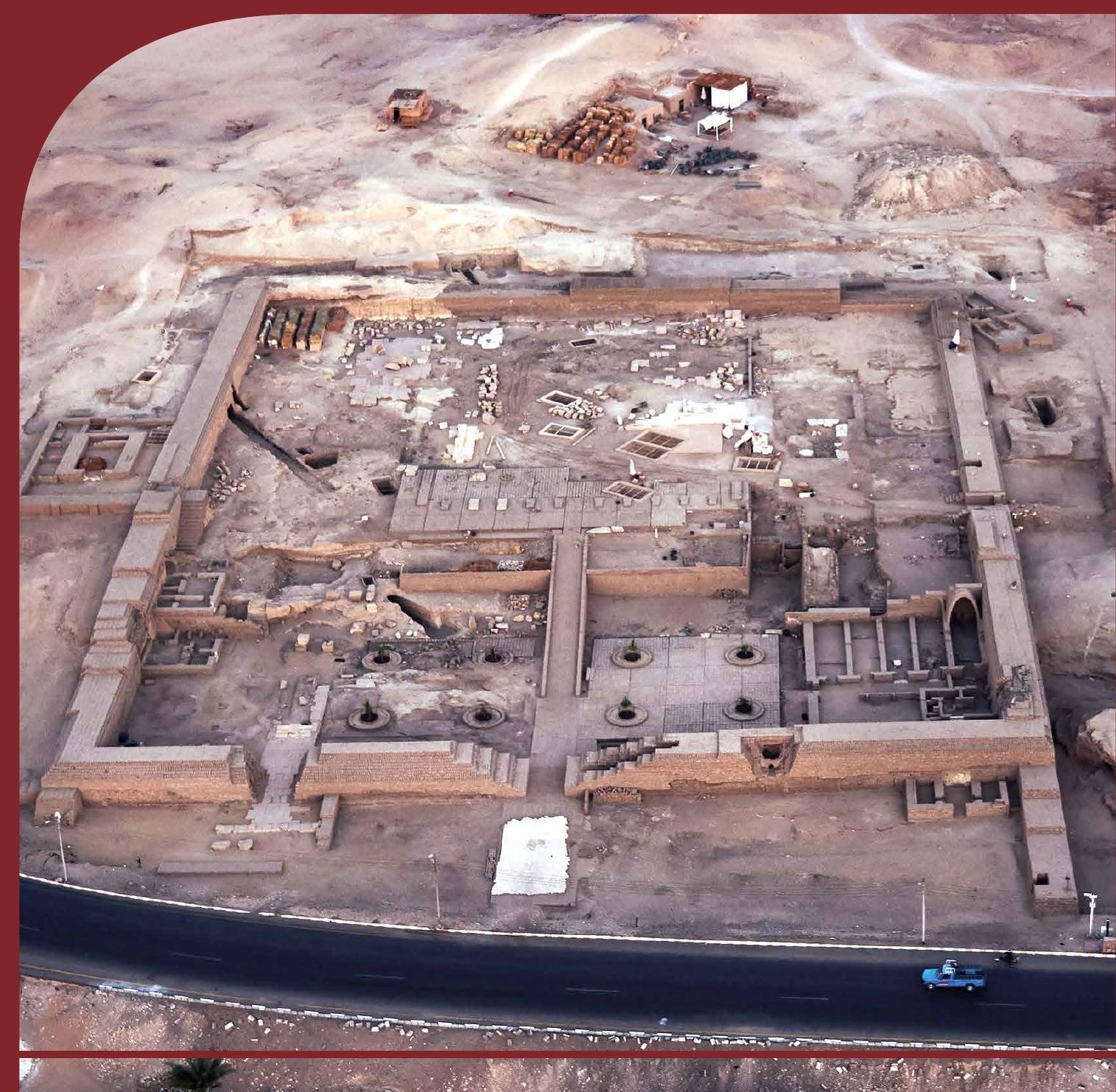

BOPIKSiO Institut des Cultures Mediterranéennes et Orientales IST PAN de l'Académie Polonáise des Sciences 


\title{
COMITÉ DE RÉDACTION SCIENTIFIQUE
}

Maciej Makowski - rédacteur en chef Jadwiga Iwaszczuk - rédacteur

Agnieszka Ryś - secrétaire de la rédaction

Ewa Laskowska-Kusztal - rédacteur thématique du volume

CONSEIL SCIENTIFIQUE DU JOURNAL

Michał Kobusiewicz (IAE PAN, Warszawa)

Ewa Laskowska-Kusztal (IMOC PAS, Warszawa)

Demetrios Michaelides (University of Cyprus, Nicosia)

Jean-Charles Moretti (IRAA-MOM, Université de Lyon 2/CNRS)

Dietrich Raue (Ägyptisches Museum der Universität Leipzig)

Paul Reynolds (ICREA, España)

Derek Welsby (British Museum, London)

COMITÉ SCIENTIFIQUE DE LECTURE

la liste des membres du comité est accessible en ligne sur

http://www.etudesettravaux.iksiopan.pl

\author{
RÉDACTION TECHNIQUE \\ Jadwiga Iwaszczuk \\ Maciej Makowski
}

REVUE DES TEXTES EN ANGLAIS

Jo Harper 
ÉTUDES et TRAVAUX XXXIII 
INSTYTUT KULTUR ŚRÓDZIEMNOMORSKICH I ORIENTALNYCH POLSKIEJ AKADEMII NAUK

\title{
STUDIA i PRACE
}

XXXIII

\author{
ROIKŚSiO \\ ESOPAN \\ WARSZAWA \\ 2020
}


INSTITUT DES CULTURES MÉDITERRANÉENNES ET ORIENTALES DE L'ACADÉMIE POLONAISE DES SCIENCES

\section{ÉTUDES et TRAVAUX}

XXXIII

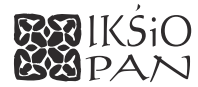

VARSOVIE

2020 
Publication scientifique financée dans le cadre du programme du Ministre de la Science et de l'Éducation Supérieure

« Programme National de Développement de l'Humanistique » pour les années 2016-2021 (projet no 3bH 150099 83)

\title{
UARODOWY PROGRAM ROZWOJU HUMANISTYKI
}

\author{
Copyright (C) \\ Instytut Kultur Śródziemnomorskich i Orientalnych PAN \\ et les Auteurs \\ Warszawa 2020
}
ISSN 2084-6762
(jusqu'en 2011 : 0079-3566)
e-ISSN 2449-9579
Version première en papier, imprimée en Pologne - 150 copies
Version électronique accessible sur
http://www.etudesettravaux.iksiopan.pl

Édition: Polskie Towarzystwo Historyczne et Wydawnictwo Neriton, Warszawa

Conception générale de la couverture : J. Iwaszczuk

Photographie de couverture : J. Pablo Moreira (C) Thutmosis III Temple Project

(Henket-ankh, le temple des Millions d'Années de Thoutmosis III, Louxor) 


\section{Table des matières}

Editorial (par Ewa Laskowska-Kusztal) ................................................................... 7

MirosŁaW BARWIK

Two Portraits of Senenmut in the Hatshepsut Temple at Deir el-Bahari

MirosŁaW BARWIK

New Prayers and Invocations to Hathor among Unpublished Dipinti

from the Thutmose III Temple at Deir el-Bahari

LiNDA CHAPON

The Decoration of the Columns and Pillars from the Henket-ankh of Thutmose III

(Western Thebes)

Abraham I. Fernández Pichel

Quelques blocs ptolémaïques inédits de la cour du IX pylône du domaine

d'Amon à Karnak

Amgad Joseph

The Stela of Haremwia, Chief of the Provisioning Sector of the Temple Workshop

(CG 34079 / JE 22011)

EWA JÓZEFOWICZ

Ramesside Inscriptions and Preparatory Sketches in the Western Wall of Portico

of Obelisks of Hatshepsut's Temple at Deir el-Bahari

Miral LASHIEN

Donkeys in the Old and Middle Kingdoms According to the Representations

and Livestock Counts from Private Tombs

AleKsandra Pawlikowska-Gwiazda

Christian Secondary Epigraphy in the Temple of Hatshepsut. Some New Remarks

KRZYSZTOF RADTKE

Square Grids in the Tomb of Akhethotep - Questions and Doubts

Myriam Seco Álvarez, JaVier Martínez Babón

The Temple of Millions of Years of the Pharaoh Thutmose III (Luxor). An Update on the Research 